\title{
Diagnostic accuracy of a new commercially available HCV-antigen test
}

\author{
Marta Monari, Serenella Valaperta, Roberto Assandri, Alessandro Montanelli \\ Clinical Investigation Laboratory, IRCCS Istituto Clinico Humanitas, Rozzano (MI).
}

Key words: HCV-infection, HCV-Ab, HCV-Ag, diagnostic algorithm

Accuratezza diagnostica di un nuovo test commerciale per la ricerca di HCV-antigene

\section{SUMMARY}

Nowadays the diagnosis of HCV infection is based on the detection of anti-HCV antibodies (HCV-Ab) subsequently confirmed by a RIBA test and HCV-RNA test.A new chemiluminescence assay is now available allowing the detection of HCV antigen ( $\mathrm{HCV}-\mathrm{Ag})(\mathrm{HCV}-\mathrm{Ag}$, Abbott, USA ${ }^{\oplus}$ ). The aim of the study was to investigate the diagnostic performances of this new test. We performed on 63 selected serum samples the following analyses: HCV-Ab , HCV-Ag, RIBA test and HCV-RNA.

For HCV-Ag vs HCV-RNA we found specificity of $95 \%$ and sensitivity of $100 \%$.

Our study has highlighted the diagnostic accuracy of HCV-Ag test. This test does not require special equipments to be performed, so its strong specificity suggests its possible role in a rapid and low-cost new diagnostic protocol, particularly in a population with low incidence of $\mathrm{HCV}$ infection.

\section{BACKGROUND}

Hepatitis $\mathrm{C}$ virus (HCV) is a major public health issue and a leading cause of chronic liver disease. The World Health Organization (WHO, 2009) estimates that about 200 milion people (about $3 \%$ of the world's population) are infected with $\mathrm{HCV}$ and 3 to 4 milion persons are newly infected each year. Moreover, at least $85 \%$ of infected persons become chronically infected and about 70\% develop chronic hepatitis.

The diagnosis of HCV infection in clinical practice, usually performed on asymptomatic patients, is carried out by detection of HCV antibodies (HCV-Ab) followed by confirmatory testing with additional HCV-Ab tests and/or HCV RNA detection (1). This procedure generate high numbers of false- positive results, increasing test time and costs per patient (2).

The aim of this study was to evaluate the role of HCV Ag assay (3) in a rapid and less-expensive diagnostic protocol (Figure I).

\section{MATERIALS AND METHODS}

The study was carried out on 63 selected samples; among these patients, 14 samples showed a potential interfering factors such as Rheumatoid Factor, HBsAg, Syfilide, HIV, IgM Toxoplasmosi, IgM Citomegalovirus and Epstein Barr Virus (Table 1).

All samples serum were analyzed with:

- HCV-Ab by the automated assay on Abbott Architect Ci16200 analyzer (cut off $\geq 1.0 \mathrm{~S} / \mathrm{CO}$ ) [HCV-Ab, Abbott ${ }^{\circledast}$, Diagnostic USA];

- HCV-Ag by the automated assay on Abbott Architect Ci16200 analyzer (cut off $\geq 0.2 \mathrm{pg} / \mathrm{mL}$; sensitivity 0.06 $\mathrm{pg} / \mathrm{mL}$ ) [HCV-Ag, Abbott ${ }^{\mathbb{}}$, Diagnostic USA];

- HCV-RNA by TaqMan Cobas Roche analyzer (limit of detection $8.8 \mathrm{UI} / \mathrm{mL}$ ) [TaqMan HCV Test, v 2.0 Roche ${ }^{\circledR}$ Molecular Systems, Branchburg, IL, USA];

- RIBA test (RIBA test Ortho Diagnostic, Raritan, NJ, USA).

All test were performed according manufacturer's recommendations.

\section{RESULTS}

HCV-Ag showed a specificity of $95 \%$ and a sensitivity of $100 \%$ with a predictive positive value (PPV) of was $92 \%$ and a predictive negative value (PNV) of $100 \%$, compared to HCV-RNA

Moreover, HCV-Ab presents a specificity of $24 \%$ and a sensitivity of $100 \%$ with a PPV of $46 \%$ and a PNV of $100 \%$, compared to HCV-RNA (Table 2).

Table I. Characteristics of potential interfering factors among anti-HCV negative samples.

\begin{tabular}{cc}
\hline POTENTIAL INTERFERING FACTORS & $\mathbf{N}^{\circ}$ SAMPLES \\
\hline Rheumatoid Factor & $\mathrm{I}$ \\
\hline $\mathrm{HbsAg}$ pos & 6 \\
\hline IgM Toxoplasmosi & $\mathrm{I}$ \\
\hline IgM Citomegalovirus & 2 \\
\hline IgM Epstein Barr Virus & $\mathrm{I}$ \\
\hline IgM Epstein Barr Virus and Citomegalovirus & $\mathrm{I}$ \\
\hline HIV & $\mathrm{I}$ \\
\hline HIV and Syphilis & $\mathrm{I}$ \\
\hline
\end{tabular}

Table 2. Results of HCV detection.

\begin{tabular}{lcccc}
\hline \multicolumn{5}{c}{ Samples } \\
& $\mathbf{2 5}$ & $\mathbf{2}$ & $\mathbf{2 7}$ & $\mathbf{9}$ \\
& $(40 \%)$ & $(3 \%)$ & $(43 \%)$ & $(14 \%)$ \\
\hline$H C V-R N A$ & + & - & - & - \\
\hline$H C V-A g$ & + & + & - & - \\
\hline$H C V-A b$ & + & + & + & - \\
\hline$R I B A$ test & + & Undet. & Undet. & Not avail. \\
\hline
\end{tabular}

\section{CONCLUSIONS}

In our study, we assessed the accuracy of HCV-Ag test for the diagnosis of HCV infection. Our preliminary data suggest that the HCV-Ag test is a rapid, less expensive and easy to perform assay. Combination of a high sensitive test (HCV$\mathrm{Ab}$ ) with a specific assay (HCV-Ag) could offer a rapid (less than one hour) and safe diagnostic protocol.

To reduce overestimation (false-positive) of HCV infection due to HCV-Ab, we propose to detect HCV-Ag in combination with HCV-Ab in all samples performed in routine clinical practice.

As suggested in Figure II, a patient with HCV-Ag-positive/ $\mathrm{HCV}-\mathrm{Ab}$ - negative is affected by an acute infection, so we can clarify the viral load by HCV RNA. On the other hand, in a patient with $\mathrm{HCV}-\mathrm{Ag}$ - positive/HCV-Ab-positive we can conclude that it is a serological picture of HCV infection. In this case HCV RNA detection is useful to understand only the thorny cases, such as "grey-zone" reactivity.

This new diagnostic algorithm can reduce the molecular-biology investigation tests with a high cost-effectiveness.

\section{Corresponding author: Marta Monari}

Laboratorio Analisi Cliniche, IRCCS Istituto Clinico Humanitas,

20089 Rozzano (MI) - Via Manzoni n 56 - Telefoni: 0282244763,0282244723 - Fax: 0282244790

E-mail: marta_noemi.monari@humanitas.it 


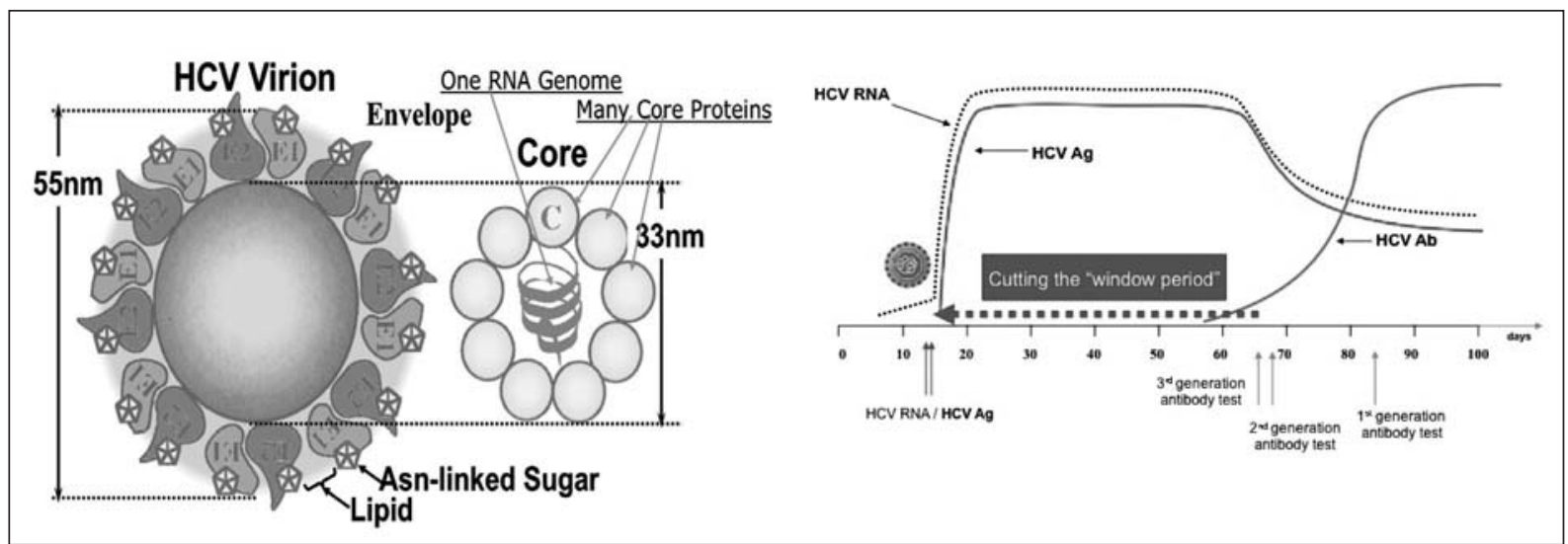

Figure I. HCV structure and the time course of markers during viral infection (by Abbott Diagnostics)

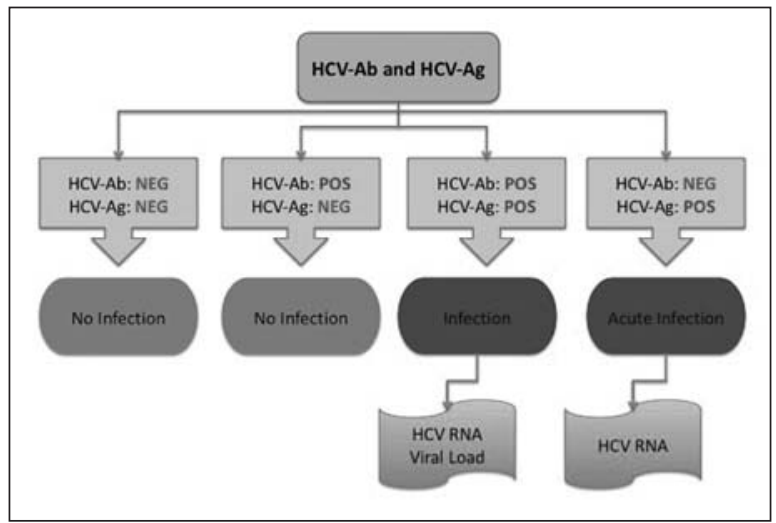

Figure II. The new diagnostic protocol.

\section{BIBLIOGRAPHY}

1. Chronic hepatitis C: current desease menagment. NDDIC 2007; NIH publication 07-4230

2. Contreras AM, Ochoa-Jménez RJ. Overestimation of HCV prevalence by assessing positivity anti HCV results only. Arch Int Med. 2009; 169, (9): 903-904

3. Morota $\mathrm{K}$ et al. A new sensitive and automated chemiluminescent microparticle immunoassay for quantitative determination of hepatitis $C$ virus core antigen. J Virol Methods. 2009 Apr;157(1):8-14. 